\title{
Assédio moral no ambiente de trabalho: propostas de prevenção
}

\author{
Kátia AlessandraPastori Terrin ${ }^{1}$ \\ Lourival José de Oliveira ${ }^{2}$
}

\section{Resumo}

\begin{abstract}
As relações desenvolvidas no ambiente de trabalho são alteradas em decorrência dos novos processos produtivos, gerando conseqüências prejudiciais à saúde física e mental dos trabalhadores e trabalhadoras, com danos à dignidade e à identidade expressos, principalmente através do assédio moral. Nesse sentido, o objetivo deste trabalho foi conhecer o assédio moral bem como as medidas e procedimentos adotados para preveni-lo. O fenômeno, apesar de antigo, passou a ser debatido na atualidade, uma vez que suas conseqüências, sempre negativas, acabam denegrindo o ambiente de trabalho, repercutindo na saúde, vida social e familiar do trabalhador, bem como no âmbito empresarial. Desta forma, diante da rapidez com que este malefício vem se desenvolvendo no ambiente de trabalho, faz-se necessária a criação de mecanismos que possibilitem uma modificação legislativa mais célere, assim como dar enfoque à políticas de prevenção, objetivando minimizar esta conduta perversa.
\end{abstract}

Palavras-Chave: Ambiente de trabalho; Assédio moral; Dano moral; Dignidade humana; Relação de trabalho.

\section{Introdução}

Diante da constante evolução do Direito, que por sua vez gera reflexos nos costumes da sociedade em um determinado momento histórico, há que se observar o atual tema do assédio moral no ambiente de trabalho, que repercute de forma significativa na vida do trabalhador e em seu meio laboral, social e familiar, merecendo, destarte, uma maior atenção.

Muito embora a discussão sobre o assunto seja atual, o fenômeno provavelmente é tão antigo quanto o próprio trabalho. No entanto, só recentemente é que seus malefícios passaram a ser vistos com outros olhos: seja pelos operadores do direito, seja por psicólogos e pesquisadores da saúde do trabalho. Ademais, a questão vem chamando a atenção por

Acadêmica do 5o ano matutino do curso de Direito da Universidade Estadual de Londrina.

Doutor em Direito (PUC-SP); professor adjunto da Universidade Estadual de Londrina; professor da UNOPAR; professor da FACCAR; professor da UNIMAR. 
suscitar inúmeros estudos, projetos de lei, reflexões e debates em todo mundo, inclusive no Brasil, no sentido de delinear e conceituar o tema.

E, quando se está diante de todo o processo histórico das relações de trabalho, pode-se claramente perceber que nem sempre a preocupação com a manutenção da ordem, visando o homem (trabalhador), foi respeitada.

Diante dessa realidade, ao se conjugar o trabalho humano degradante com uma série de pesquisas sobre as condições mínimas de saúde no ambiente de trabalho, analisando-os no contexto da globalização, pode-se observar a inserção de uma figura cuja presença acabou se tornando indesejada para aqueles que sofrem com suas conseqüências, qual seja, o assédio moral no ambiente de trabalho.

Observa-se que o empregador, na ânsia de cada vez mais auferir lucros e benefícios para si próprio, acaba se esquecendo que o mercado de trabalho é composto por seres humanos munidos de sentimentos, vontades e direitos a serem respeitados. E é nessa busca desenfreada pelo acúmulo de riquezas que o assédio moral ganha espaço e destrói aqueles cuja importância é cada vez maior dentro do cenário de desenvolvimento econômico.

De posse desses contornos iniciais destaca-se as formas pelas quais o assédio moral costuma se difundir no ambiente de trabalho, atacando não só o psicológico, mas a saúde física do trabalhador, bem como suas conseqüências, diretas ou indiretas, no meio social, empresarial e para o Estado como um todo. Dando ênfase às formas de prevenção utilizadas pelas empresas, sindicatos e o Ministério Público do Trabalho que buscam minimizar e coibir a prática repugnante do assédio moral.

\section{Introdução ao estudo do assédio moral}

As relações de trabalho tiveram, ao longo da história, diferentes enfoques de proteção. Primeiramente, o que se visava preservar era a própria vida do trabalhador frente às máquinas extremamente agressivas e o meio ambiente físico que a ceifava. Com o início da 1a Guerra Mundial, a reivindicação passou a ser por proteção voltada para a manutenção da qualidade de vida no trabalho.

Finalmente, em 1968, na Europa, a luta que mobilizou a ação sindical voltou-se para medidas preventivas da higidez mental do trabalhador (DEJOURS, 2000, p. 23), e é sobre esse prisma que o presente estudo se desenvolverá. 
Em um novo ambiente de trabalho, forjado pela globalização e a modernização, indústrias e empresas vêm cada vez mais forçando o seu ritmo de trabalho na luta pelo lucro. A organização do trabalho com a sua estruturação hierárquica, divisão de tarefas, jornadas de trabalho em turnos, ritmos, intensidade, monotonia, repetitividade e responsabilidade excessiva são fatores que contribuem para desencadear uma série de distúrbios ao trabalhador, sejam elas físicas ou psíquicas.

O processo de globalização, ao mesmo tempo em que propicia a internacionalização do sistema produtivo de serviços, começa a evidenciar a necessidade de se buscar, de forma mais concreta, imediata e progressiva, a solução de necessidades prementes para garantir a sobrevivência da humanidade, que deixa de ser uma abstração, para se converter numa realidade (SILVA, 2003, p. 142).

A modernização do Direito do Trabalho deve vir através de um processo de atualização, sempre buscando o atendimento dos princípios constitucionais da valorização do trabalho, da dignidade da pessoa humana, da produção da justiça social, através da elevação do nível de vida do trabalhador e não na busca do barateamento da mão-de-obra, com a conseqüente coisificação do homem (SILVA, 2003, p. 143).

Tudo isso tem contribuído para gerar um certo distanciamento entre as pessoas dentro da empresa, um grau tamanho de impessoalidade com a conseqüente adoção de procedimentos moralmente reprováveis. Envolvido nessa rotina de aumento da produtividade, o trabalhador nem sempre percebe o problema - ou para piorar, passa a ser cúmplice do próprio martírio, aumentando sua jornada, tornando-se um adversário dos colegas para demonstrar suas capacidades e reduzindo prazos e equipes, para não ser apontado como peça discordante do sistema.

De posse desses contrapontos iniciais, deve ser analisanda a atual conjuntura enfrentada pelos trabalhadores ante a ausência de uma proteção legislativa por parte da $\mathrm{CLT}$, mas com um sopro de esperança frente a novos projetos de leis em âmbitos territoriais diferentes, embora com objetivos idênticos e resultados cada vez mais inesperados. Dando enfoque, como prioridade, a formas de prevenção ao assédio moral no ambiente de trabalho.

Diante das altas taxas de desemprego que refletem na instabilidade econômica, da competição capitalista e as inovações tecnológicas e da crescente concorrência, o mercado 
de trabalho tornou-se mais exigente. Em conseqüência disso, a busca desenfreada pelo poder influencia o âmago de algumas pessoas e as fazem tornar o ambiente de trabalho um lugar de conflitos sem escrúpulos. O homem está fragmentado porque não trabalha em um ambiente adequado e não há valorização do seu trabalho (MAZZNI, 2006).

O trabalho, que a princípio era voltado ao domínio da natureza é deturpado para dominar o homem. Residente na base do sistema econômico da atualidade, na condição de componente fundamental, foi ele subordinado aos interesses do capital, transpondo suas características para os demais espaços societários, particularmente o político e o jurídico.

Pode-se afirmar que o assédio moral nas relações de trabalho é um dos problemas mais sérios enfrentados pela sociedade atual. Conforme visto, ele é fruto de um conjunto de fatores, tais como a globalização econômica predatória, vislumbradora somente da produção e do lucro, e a atual organização de trabalho, marcada pela competição agressiva e pela opressão dos trabalhadores através do medo e da ameaça (FERREIRA, 2004, p. 33).

Em que pese o tema em questão seja alvo de atual discussão no âmbito justrabalhista, no que tange às decisões jurisprudenciais, este fenômeno tem se expandido notavelmente nos últimos dez anos, influindo no meio ambiente de trabalho com conseqüências pós-traumáticas ao trabalhador assediado quando a situação é habitual e inerente às condições de trabalho e o ambiente laboral é hostil, intimidatório e humilhante.

O termo "mobbing", conhecido como terror psicológico ou assédio moral, foi empregado pela primeira vez pelo etiologista Heinz Lorenz, ao definir o comportamento de certos animais que circundavam ameaçadoramente outro membro do grupo, provocando sua fuga por medo de um ataque (RUFINO, 2006, p. 21).

Como já frisaram alguns autores estudiosos do tema, o assédio moral é inerente ao aparecimento da civilização humana. Contudo, o tema é recente como foco de discussões no Brasil e mesmo nos demais países. Mas o fenômeno expande-se de tal forma que países como França, Estados Unidos, Alemanha, Itália, Austrália e Suécia já estão inserindo em suas legislações, dispositivos para a redução e punição dos casos. E em outros, como Chile, Uruguai, Portugal, Suíça e Bélgica há Projetos de Lei (MENEZES, 2002, p. 193).

No Brasil, a primeira matéria referente ao assunto foi publicada no jornal Folha de São Paulo, em 25 de novembro de 2000, como resultado da pesquisa realizada por Margarida Barreto, em sua dissertação de Mestrado em Psicologia Social defendida em 22 
de maio de 2000 na Pontifícia Universidade Católica de São Paulo, sob o título "Uma jornada de humilhações".

A pesquisa realizada por Margarida Barreto, entre 2001 e 2005, em todos os estados brasileiros, mostrou que o assédio moral acontece de Norte a Sul do País. De um universo de 42,4 mil trabalhadores de empresas públicas, privadas, governos e organismos não-governamentais, dez mil haviam sofrido algum tipo de humilhação no trabalho. 0 assédio moral se manifesta das mais diferentes formas, sendo que a principal delas é a pressão para produzir mais e prolongar a jornada de trabalho. As humilhações psicológicas exercidas por chefes e colegas são manifestações cada vez mais comuns (BARRETO, 2006).

No mesmo ano a Editora Bertrand Brasil publicou o livro de Hirigoyen que denuncia o fenômeno, notadamente nos países europeus. A partir desse momento o tema passou a ser discutido por vários setores da sociedade, principalmente os sindicatos de trabalhadores, e muitas ações judiciais baseadas nesse tipo de agressão contra a pessoa tiveram desfecho favorável.

Nos últimos anos muito se tem discutido e algumas ações já têm sido desenvolvidas para reprimir o assédio moral, mas estas medidas ainda são insuficientes. É preciso que o tema se mantenha à tona e que as vítimas manifestem-se: reagindo, denunciando e evitando o agravamento do problema.

\subsection{Conceito de assédio moral}

O assédio moral no âmbito justrabalhista é a exposição de trabalhadores e trabalhadoras a situações que são humilhantes e constrangedoras. Essas situações perfazem-se de forma repetitiva e prolongada.

Há que se ressaltar que esse tipo de situação ocorre mais facilmente em relações hierárquicas autoritárias, de um ou mais chefes dirigidas a um subordinado, desestabilizando a relação da vítima com o ambiente de trabalho e a organização.

Contudo, deve-se notar que o assédio moral na relação chefe-subordinado não é exclusiva, podendo ocorrer o assédio horizontal, cuja ocorrência se dá entre colegas de trabalho da mesma hierarquia, e até mesmo o assédio misto, quando um subordinado ou grupo de subordinados se unem a um superior hierárquico para assediarem um colega de trabalho. 
O assédio moral, ou terror psicológico como também é conhecido, destina-se a definir uma violência pessoal, moral e psicológica. Nada mais é do que uma forma de submissão do trabalhador a situações vexaminosas, constrangedoras e humilhantes, de maneira reiterada e prolongada, durante a jornada de trabalho ou até mesmo fora dela, em razão das funções que exerce.

É conceituado também como uma conduta abusiva (gestos, palavras, comportamentos, atitudes...) que atente, por sua repetição ou sistematização, contra a dignidade ou integridade psíquica ou física de uma pessoa, trazendo como conseqüências, a degradação do ambiente de trabalho, a vulnerabilidade e desequilíbrio da vítima, dentre outras. Resultando, dessa forma, sérios riscos à saúde física e psicológica do trabalhador e às estruturas da empresa e do Estado.

Para a especialista no assunto, Marie-France Hirigoyen, pode-se utilizar o seguinte conceito para o assédio moral:

Por assédio moral em um local de trabalho temos que entender toda e qualquer conduta abusiva manifestando-se, sobretudo, por comportamentos, palavras, gestos, escritos, que possam trazer dano à personalidade, à dignidade ou à integridade física ou psíquica de uma pessoa, pôr em perigo seu emprego ou degradar o ambiente de trabalho (HIRIGOYEN, 2002, p. 67).

Com efeito, identifica-se por qualquer ato que viole a dignidade do trabalhador, atitudes humilhantes que vão desde o isolamento, passando pela desqualificação profissional e acabando no terrorismo, com vistas à destruição psicológica da vítima.

Ressalta-se que o assédio moral passou a ser enfocado basicamente sob o prisma laboral, em razão da repercussão mundial de seus efeitos e por ser o ambiente de trabalho o mais propício ao desenvolvimento desse tipo de fenômeno. Diga-se até mesmo em razão do capitalismo moderno e suas ingerências, fomentadas pela idéia de globalização e exigência de um perfil de competitividade do trabalhador moderno.

A velha empresa, pautada na organização vertical centrada no poder diretivo, na hierarquia e na subordinação dos assalariados, sempre teve a competição como regra. A empresa pós-moderna, leve, enxuta, que executa o trabalho por rede, elevou a competição interna e externa a uma verdadeira guerra, sem compaixão pelo vencido (GUEDES, 2006, p. 23). 
Conforme mencionado anteriormente, o assédio moral corresponde a um fenômeno típico da sociedade atual, não se restringindo a uma região específica, mas constituindo um problema com amplitudes cada vez mais globais. Apesar disto, a forma como se manifesta varia de local para local, o que acaba por dificultar sua definição e estabelecimento de uma única terminologia.

Cada localidade em específico vem, à sua maneira, atribuindo uma denominação, aliada a uma conceituação, diante da forma como o assédio se realiza perante seus olhos. A pesquisa mais completa foi realizada por Hirigoyen, pois ela selecionou visões diversificadas do fenômeno em vários países.

Seja como for, o ataque de um grupo ou ataque individual, seja com intenção declarada de destruir o outro, seja de modo velado, seja por adaptar empregados ao sistema, seja para forçá-los a deixá-lo, o assédio moral tira do homem sua dignidade como pessoa humana e como trabalhador que deseja ver seu trabalho valorizado.

Assim, nota-se que mesmo possuindo diversas denominações, a base utilizada para a agressão é sempre a mesma, os atos são variados, mas o objetivo é sempre o mesmo: minar o psicológico do trabalhador de forma que este venha a ser retirado de seu ambiente de trabalho.

\subsection{Conseqüências do assédio moral para as vítimas, empresa e o Estado}

Os efeitos do assédio têm estilo específico que devem ser diferenciados do estresse, da pressão, dos conflitos velados e dos desentendimentos.

Quando o assédio moral ocorre é sempre precedido da dominação psicológica do agressor e da submissão forçada da vítima. A pessoa tomada como alvo percebe a má intenção de que é objeto sendo ferida em sua auto-estima, sentindo-se atingida em sua dignidade com uma perda súbita da autoconfiança, levando-a a ter necessidade de tratamento médico ou mesmo internação em clínica de saúde psicológica (HEMÉRITO, 2006, p. 10).

As conseqüências às vítimas de assédio moral estão diretamente ligadas com fatores que se relacionam com a intensidade e a duração da agressão. As conseqüências específicas em curto prazo são o estresse e a ansiedade combinado com um sentimento de impotência e humilhação. Destes prejuízos decorrem perturbações físicas: cansaço, 
nervosismo, distúrbios do sono, enxaqueca, distúrbios digestivos, dores na coluna, etc. Digase que tais conseqüências seriam uma autodefesa do organismo a uma hiperestimulação, que a longo prazo, pode dar lugar ao choque, à ansiedade, ou até mesmo a um estado depressivo (SANTOS, 2003, p. 143).

Sem dúvida alguma os danos na esfera emocional também são desastrosos. São comuns as crises existenciais, de relacionamento e econômica que acabam por desestabilizar a vida familiar e social da vítima.

Pesquisas realizadas em diversos países confirmam esses dados e demonstram que o assédio moral tem repercussões diretas sobre o estado psicofísico das vítimas, desencadeando doenças de origem psicossomáticas e, num grave extremo, pode conduzir à invalidez psíquica, dando ampla razão àqueles que sustentam que o assédio moral deva ser caracterizado como uma doença profissional.

Seguindo esta linha de pensamento pode-se citar o estudo feito por Gustavo Barbosa Garcia (2005, p. 87), onde conclui que

\footnotetext{
a doença profissional é aquela produzida ou desencadeada pelo exercício do trabalho peculiar a determinada atividade, bem como a doença do trabalho é aquela adquirida ou desencadeada em função de condições especiais em que o trabalho é realizado e com ele se relacione diretamente.
}

Ademais, é interessante abrir um parêntese para demonstrar os danos ao patrimônio da vítima. Uma vez identificada a gravidade das repercussões do assédio moral no campo da saúde da vítima, é importante estabelecer que os danos não se limitam a esse contexto.

Uma vez integrante do processo de assédio moral, a vítima acaba por reduzir sua capacidade de trabalho, gerando prejuízos em seu patrimônio, à medida que as agressões passam a fazer parte de seu cotidiano, repercutindo nas oportunidades de gerar ganhos em razão do trabalho.

Contudo, deve-se frisar que os efeitos perversos do assédio moral não atingem somente a pessoa imolada, mas se estende também, em termos de custos, para as empresas que respondem pelas conseqüências diretas no interior do grupo de trabalho e até mesmo ao Estado. 
As empresas sofrem conseqüências com a prática do assédio moral, principalmente no que diz respeito ao aumento de custos que é determinado pelas faltas decorrentes de doenças, substituições e despesas com processos judiciais, além de redução na capacidade produtiva e na eficiência do trabalhador, que poderá ter um rendimento inferior a $60 \%$ (GUEDES, 2006, p. 115).

Importante destacar também não só os danos à produtividade da empresa, mas também os dispêndios financeiros face às indenizações que possam vir a ser condenados na Justiça.

Contudo, os danos decorrentes da violência moral no trabalho não se limitam às vitimas e às empresas. O Estado paga um alto custo, tanto no que diz respeito à saúde pública, quanto às aposentadorias precoces.

Ademais, conforme demonstram pesquisas, o maior percentual de assédio moral encontra-se no serviço público, o que por si só já encerra relevantes prejuízos à dinâmica organizacional do Estado.

Pode-se verificar que as conseqüências sofridas pelo Estado estão esculpidas em três pontos principais: custos direcionados à previdência social, à política trabalhista e de saúde pública.

Com relação aos custos com a previdência social, além das licenças médicas mais longas, observa-se também as aposentadorias precoces por invalidez, que geram um aumento de despesas ao Estado.

Já à política trabalhista, caracteriza-se uma vez que um dos pilares de um país é, sem dúvida, a capacidade produtiva de sua economia. E o assédio moral afeta a empresa e o trabalhador, corroendo a produtividade e a própria imagem do empreendimento, repercutindo negativamente ao Estado, por conseguinte.

No tocante à política de saúde, os custos de tratamento de patologias oriundas do processo de assédio moral são bastante significativos.

Dessa forma, o assédio moral no ambiente de trabalho repercute de forma bastante danosa em diversos setores organizacionais do Estado, explicitando cada vez mais a necessidade de políticas que previnam e coíbam essa prática. 


\section{0 assédio moral nas relações de trabalho e os princípios consitucionais de proteção}

O assédio moral envolve uma questão de ordem constitucional, uma vez que viola princípios e garantias estabelecidos na Constituição Federal de 1988. Envolve ainda direitos e liberdades há muito conquistados pelos trabalhadores, expressos tanto na CLT como em leis esparsas.

Segundo Maria Aparecida Alkimim (2005, p. 11), o assédio moral sob a ótica jurídica viola os princípios da boa-fé, respeito, não-discriminação, ferindo a personalidade e dignidade do empregado, além de lhe gerar problemas de saúde, desemprego e até o suicídio.

Destarte, torna-se indispensável analisar o tema proposto sob a ótica constitucional, enfocando de quais formas o assédio moral viola os princípios constitucionais, bem como o da dignidade humana e a valorização do trabalho humano, visto que é através destes dois princípios primordiais e indisponíveis que nascem os direitos de qualquer cidadão que venha a ocupar o mercado de trabalho.

Observa-se que o ordenamento jurídico constitucional brasileiro erigiu o trabalho e a dignidade humana como pilares do Estado Democrático de Direito (CF/88, art. 1으, incs. III e IV), bem como proclamando na ordem econômica a valorização do trabalho (CF/88, art.170).

Pode-se afirmar ainda que a Carta Magna de 1988 atribuiu à dignidade humana a categoria de princípio fundamental, uma vez que protege os atributos inerentes à pessoa humana, tais como a vida, a liberdade, igualdade, intimidade, privacidade, trabalho, saúde, meio ambiente protegido, educação, dentre outros (ALKIMIM, 2005, p. 17).

Ensina Rilma Aparecida Hemérito (2006, p. 8), em sua obra dedicada ao assédio moral no trabalho, que na sociedade pós-industrial o Direito do Trabalho voltou-se para a busca do respeito aos direitos fundamentais dos trabalhadores, objetivando fixar parâmetros de igualdade. E que estes direitos fundamentais passam a ter uma função limitadora do exercício do poder do empregador, e representam uma barreira contra a flexibilização das condições de trabalho mediante negociação coletiva.

Observa-se ainda que o empregador deve ater-se à concretização dos valores que o Direito do Trabalho pretende realizar, encontrando seus limites na dignidade do ser humano, uma vez que é o detentor do poder diretivo e disciplinar. Ademais, possui o dever 
de proporcionar condições garantidoras do bem-estar físico e mental do trabalhador, empenhando-se em coibir todos os excessos.

\section{Propostas de prevenção ao assédio moral}

O assédio moral muitas vezes aniquila as vítimas, ocasionando seqüelas psíquicas, físicas e patrimoniais. É nesse momento que surge o Direito servindo como censor a destinar instrumentos de prevenção, repressão e desestimulo a prática do assédio moral (SILVA, 2005, p. 06).

"Todo assédio moral pode constituir um perigo para a saúde do trabalhador" (MENDONÇA, 2001, p. 154). E é principalmente sobre ele que a prevenção se faz mais necessária.

Aponta Luciany Pereira dos Santos (2003, p. 151) que a tendência moderna em termos de reparação de danos é justamente a prevenção, mormente porque os danos de natureza não patrimonial não se conformam com a tutela ressarcitória. Daí surge a necessidade de se criar e aplicar mecanismos de tutela preventiva de danos a direitos da personalidade.

No Brasil a Consolidação das Leis trabalhistas ainda não contém dispositivos específicos para a prevenção do assédio moral, uma vez que sua elaboração se deu em uma época onde a preocupação com o empregado se limitava ao aspecto de sua integridade física. Suas normas não alcançavam a proteção da integridade psicológica ou moral do trabalhador.

No entanto, não significa que inexistam meios jurídicos para a prática de prevenção. Ilustra Martha de Mendonça que uma Convenção Coletiva de Trabalho, por exemplo, poderia estabelecer para o empregador a obrigação de prevenção do assédio moral, impondo, inclusive, sanções ao agressor. Um exemplo que deu certo na companhia Volkswagen na Alemanha, que possui normas anti-mobbing desde o ano de 1996, o que acarretou na redução para $1 \%$ das condutas perversas, gerando, destarte, uma poupança de 50 milhões de dólares por ano, desde então (MENDONÇA, 2001, p. 154).

Algumas propostas de prevenção cada vez mais estão sendo utilizadas e com resultados positivos para a obtenção de um ambiente de trabalho mais sadio e propício, implicando conseqüentemente na inibição e diminuição da prática do assédio moral. Dentre 
elas citam-se as políticas sindicais de prevenção, as ações empresariais, a intervenção do Ministério Público do Trabalho e os Projetos de lei.

\subsection{Políticas sindicais de prevenção do assédio moral}

Sindicatos são entidades associativas permanentes que representam, respectivamente, trabalhadores vinculados por laços profissionais e laborativos comuns, e empregadores visando tratar de problemas coletivos das respectivas bases representadas, defendendo seus interesses trabalhistas e conexos, com o objetivo de lhes alcançar melhores condições de labor e vida (DELGADO, 2006, p. 1.323).

Nesse sentido, as parcerias entre sindicatos, estudiosos e especialistas do fenômeno, demonstram que esse é um caminho seguro a ser explorado.

Um claro exemplo é o estudo sobre o assédio moral feito pelo Sindicato dos Bancários de Pernambuco em parceria com a ONG canadense Fundo para a Igualdade de Gêneros - FIG - que está esclarecendo patrões e empregados sobre um problema que já afeta $40 \%$ dos bancários. O projeto "Assédio moral na categoria bancária - Uma experiência no Brasil", além de ampla pesquisa, incluiu palestras e cartilha que está sendo distribuída para os trabalhadores dos bancos em todo o país.

Na Itália, a PRIMA - Associação para combate do mobbing e estresse social, oferece cursos de defesa pessoal, como por exemplo, Autodefesa Verbal - um curso singular que ensina regras e estratégias fundamentais para defender-se dos ataques verbais; e Egoísmo São - um curso irreverente que ensina cada um dos participantes a reconquistar a si mesmo e o domínio dos próprios pensamentos e expectativas, tornando-se independentes das limitações e influencias do ambiente circundante (GUEDES, 2006, p. 167).

O marketing social também tem sido uma ótima arma dos sindicatos para combater a conduta perversa, na medida que ajudam na conscientização e combate dessa prática.

A participação dos Sindicatos no processo de formação e mudanças, na medida em que são representantes dos trabalhadores, se faz de extrema valia. Schirlei Azevedo Ribeiro (2005) defende que é obrigação dos sindicatos colocar a segurança e saúde das trabalhadoras e trabalhadores, durante as negociações coletivas, em primeiro plano. Abrir as portas da entidade para as denúncias. Formar seus coordenadores e coordenadoras, que são 
as referências da classe a qual representam para perceberem a dor daquele que chega até o sindicato.

Assim, é indubitável afirmar que a atuação dos sindicatos seja na forma de palestras, cartilhas expositivas, seja através de mecanismos práticos de conscientização e informação sobre fenômeno, colaboram de forma louvável na prevenção do assédio moral. Restando, portanto, aos entes sindicais, desempenharem seu papel primordial de defensores da classe trabalhista.

\subsection{Ações empresariais de prevenção}

Ainda que economistas demonstrem que os custos do assédio moral são bem mais elevados do que a prevenção, no Brasil, por razões culturais, em regra, não tem sido prioridade patronal o investimento na prevenção. Alguns estudiosos dizem que raramente razões econômicas são capazes de persuadir organizações para implementar um programa de combate ao terror psicológico. O que, no entanto, constitui um grande equívoco, posto que, como demonstrado por algumas empresas multinacionais, o investimento nessa área representa um bom negócio em termos econômicos, pois se de um lado diminui custos, de outro melhora a qualidade e produtividade, que hoje são fatores indispensáveis para a competitividade do mercado (MELO, 2005, p. 213).

Já a pressão social, todavia, é um fator capaz de levar uma empresa a adotar programas sociais de prevenção. De um lado a opinião pública contra a companhia depois da divulgação de um caso de mobbing; de outro a pressão proveniente do marketing social das organizações sindicais dos trabalhadores (GUEDES, 2006, p. 162).

É notório, no entanto que medidas como mudanças nas condições de trabalho, no comportamento da direção, melhoria da condição social de cada indivíduo, bem como melhorias de padrão de modalidade do setor, contribuem de forma significativa para um melhor ambiente de trabalho (GUEDES, 2006, p. 163), repercutindo dessa forma nas condutas dos empregados, prevenindo a ocorrência de atitudes perversas como o assédio moral.

A importância de métodos preventivos ao assédio moral é indiscutível. 0 ordenamento jurídico brasileiro estabelece que o empregador é responsável pelos atos de seus empregados, bem como incumbe àquele a reparação ao dano sofrido pelo trabalhador, 
motivo pela qual a empresa deve buscar se precaver da ocorrência desses atos, uma vez que pode vir a ser punida até mesmo por sua negligência.

Como métodos de prevenção adicionais, estudiosos sugerem treinamentos para gerentes com incorporação de habilidades para reconhecer conflitos e tratá-los de forma mais produtiva (GUEDES, 2006, p. 163). Ao lado da possibilidade de redefinir as condições de trabalho, adotando regras para proteger as queixas dos indivíduos que temem represálias da coletividade, assim como a figura de um moderador que tentará de todas as formas levar as partes envolvidas a tomarem uma decisão por si mesmas, auxiliando no conflito entre as partes.

\subsubsection{Implantação de Código de Ética para as Empresas}

Quando o assédio moral no ambiente de trabalho é trazido à baila não se pode deixar de abordar aspectos éticos que circundam a problemática. É indiscutível que estabelecer parâmetros éticos e morais é de grande relevância.

Sugere Jorge Luiz de Oliveira da Silva $(2005$, p. 8) que constituem-se poderosos instrumentos para a prevenção do assédio moral, conscientizar e fomentar bons valores e princípios e estabelecer programas e políticas tendentes a consolidar parâmetros éticos no ambiente de trabalho.

E apesar da vitória do movimento sindical quanto à inserção dos códigos de éticas das empresas, do tema Assédio Moral, cumpre observar que somente isso não basta!

É necessário que as empresas reconheçam as causas da violência moral no ambiente de trabalho fundamentalmente aquelas relacionados aos novos modelos de gestão (organização de trabalho), sem esquecer que é dever dos empregadores garantir condições de trabalho adequadas e que não coloquem em risco a saúde e segurança dos trabalhadores e trabalhadoras.

A violência moral é um risco invisível e como tal deve ser eliminado através de informação e sensibilização coletiva, práticas preventivas e fundamentalmente mudanças na organização de trabalho. 


\subsection{Intervenção do Ministério Público do Trabalho}

Pode-se afirmar que com o advento da Constituição Federal de 1988, o Ministério Público alcançou maior crescimento. Deixou de ser mero apêndice do Poder Executivo, tal como previsto na EC n. 01/69, para se transformar em instituição permanente, autônoma, independente e essencial à função jurisdicional do Estado, incumbindo-lhe a defesa da ordem jurídica, do regime democrático e dos interesses sociais e individuais indisponíveis (LEITE, 2007, p. 173).

Entre suas principais metas institucionais de atuação destaca-se o combate a todas as formas de discriminação no trabalho, bem como a defesa do meio ambiente laborativo.

O Ministério Público atua na defesa dos direitos indisponíveis do trabalhador (direito à vida, à liberdade, à saúde, à segurança e ao trabalho, dentre outros). Para tanto utiliza-se de inquérito civil e outros procedimentos administrativos para assegurar a observância dos direitos sociais, bem como ajuizar ação civil pública no âmbito da Justiça do Trabalho para a defesa dos interesses metaindividuais dos trabalhadores (LEITE, 2007, p. 170).

Diante disso, o parquet pode desempenhar um papel decisivo na defesa das vítimas do assédio moral, seja através da ação coletiva em defesa do grupo de trabalhadores ofendidos pelos atos do sujeito perverso, seja por meio da condução de ajustes de compromisso bilateral (GUEDES, 2006, p. 169).

Só no ano de 2006, o Ministério Público do Trabalho abriu 337 investigações (mais do que o dobro das instauradas em 2005) para apurar casos de assédio denunciados em empresas dos setores têxtil, cosmético, farmacêutico, químicos, metalúrgico, financeiro e estatal. Em 15 regionais do MPT no país, 48 empresas firmaram termos de ajustamento de conduta com o compromisso de corrigir atitudes que se caracterizaram como assédio moral. No ano passado, 32 termos foram assinados pelas empresas.

Uma outra prática que vem sendo desempenhada pelo Ministério do Trabalho e que está rendendo bons frutos é a elaboração de cartilhas e documentos sobre o assédio moral. Como exemplo destaca-se o fruto de uma importante parceria mantida com a Delegacia Regional do Trabalho em Santa Catarina e o Ministério Público do Trabalho, na elaboração do documento sobre "Assédio Moral e o Mundo do Trabalho", que vem tendo ampla repercussão, em âmbito nacional, e que, inclusive, já deu origem a uma cartilha sobre 
o assédio moral nas relações do trabalho. Essa cartilha, através de linguagem acessível, visa a esclarecer trabalhadores sobre o fenômeno, com vistas, principalmente, a propiciar-lhes meios de defesa contra os consideráveis transtornos gerados por essa espécie de abuso (ZIMMERMANN, 2003, p. 99).

\subsection{Análises de projetos de lei}

Por tratar-se de um tema extremamente recente no tocante a previsões legislativas tendentes a abolir seu campo de atuação, serão feitas menções a textos legais que podem ser encontrados em âmbitos Federais e Municipais, uma vez que no que se refere à Consolidação das Leis do Trabalho, o assédio moral não deveria ser considerado um assunto novo.

Ocorre que a CLT, desde o ano de 1943, prevê, como motivos de rescisão indireta do contrato de trabalho (hipótese de rescisão de iniciativa do empregado por culpa do empregador), que podem ser invocados para respaldar eventual ação de indenização por assédio moral, apenas duas hipóteses de falta grave do empregador: quando forem exigidos serviços superiores às forças do empregado, defesos por lei, contrários aos bons costumes, ou alheios ao contrato (artigo 483, alínea "a"), e quando o empregado for tratado pelo empregador ou por seus superiores com rigor excessivo (artigo 483, alínea "b") (DELGADO, 2006, p. 1.210).

Do contrário, a mesma ainda não possui tópico próprio para o tratamento do assunto, assim como o diploma legal da esfera penal, que também ainda não foi capaz de definir o assédio moral como crime, embora doutrinariamente falando, já possui todos os elementos necessários para ser qualificado como tal.

No entanto, o Brasil é o país onde mais se produziu normas específicas sobre o assédio moral. Diversos Estados e Municípios já possuem lei de proteção contra o assédio moral no âmbito da Administração Pública (SILVA, 2005, p. 158). Contudo, trata-se de uma produção legislativa concentrada, uma vez que somente possui incidência em relação aos servidores públicos.

Há que se ressaltar que, em que pesem as leis até então promulgadas referirem-se tão somente aos servidores públicos, os empregados regidos pela Consolidação das Leis do Trabalho, ou mesmo os que não tenham contrato de trabalho assinado, podem buscar 
amparo, na Carta Magna brasileira, em seu artigo 5으, incisos V e X, que assegura o respeito à dignidade humana, à cidadania, á imagem, com indenização por danos morais.

No Brasil, onde cresce o reconhecimento e debate sobre os efeitos nefastos da violência moral e o estudo de medidas com o objetivo de coibir tal prática, é necessário estimular os legisladores para que esbocem uma legislação específica sobre o assunto.

Diversos projetos de lei tramitam no Congresso Nacional com o objetivo de regular a questão do assédio moral. Dentre tais projetos destacam-se os que alteram o Código Penal e um que altera a Consolidação das Leis do Trabalho. Há ainda Projetos de Lei no âmbito Federal, que se encontram em tramitação, apresentando o assédio moral nos mais variados aspectos.

Destaca-se o projeto de lei no 4.742/2001 que criminaliza a conduta do assédio moral no ambiente de trabalho, objetivando criar o artigo 146-A do Código Penal, e ainda o Projeto de Lei no. 5.970/01, tendo por objetivo acrescentar à Consolidação das Leis do Trabalho dispositivos relacionados à coação moral no ambiente de trabalho, almejando conceder ao empregado o direito de rescindir o contrato de trabalho em caso de coação moral, humilhação ou abuso de poder, sendo o empregador obrigado a pagar todos os direitos trabalhistas (OLIVEIRA, 2004, p. 60).

Contudo, cumpre salientar que qualquer que seja a mudança que venha ocorrer na legislação, não será o suficiente para coibir todas as práticas de abuso de poder no âmbito do trabalho. Infelizmente a justiça em nosso país se mostra morosa e, provavelmente, a configuração da prática de assédio moral gerará delongas processuais. No entanto, cabe ainda ao Poder Judiciário dificultar tal prática, através da aplicação severa de todas as medidas cabíveis contra os assediadores.

\section{Conclusão}

O assédio moral ou psicoterrorismo não pode ser visto como um fato isolado. Baseia-se na repetição ao longo do tempo de práticas vexatórias e constrangedoras por parte dos superiores hierárquicos, ou até mesmo de colegas de trabalho, tendentes a destruição deliberada, de todas e quaisquer condições sadias de trabalho, interferindo sobremaneira na pessoa do empregado, na medida em que influi negativamente em seus atributos profissionais e pessoais. 
Sua prática pode-se dar de forma vertical, quando é praticado por superiores hierárquicos; horizontal quando advinda de colegas de trabalho e até mesmo na forma mista, envolvendo superiores e trabalhadores que tentam desestabilizar a vítima.

A prática abusiva do assédio moral no ambiente de trabalho afeta a auto-estima e produtividade do trabalhador, refletindo, por conseguinte, no seu convívio familiar e social. Além de prejudicar a saúde psíquica e física, desencadeando um processo de desemprego, economia informal e conseqüentemente, aumento da pobreza.

Diante dessa avalanche de casos de violência do fenômeno, a primeira indagação que salta é se o ordenamento jurídico brasileiro, visto em todo o seu conjunto, dispõe de normas capazes de coibir o assédio moral, e se ainda, mesmo em virtude da inexistência de norma geral expressa de proteção ao empregado, a legislação trabalhista em vigor protege a vítima, ou se eficazmente aplicadas as atuais disposições da CLT, estas poderão colimar na punição ao trabalhador.

A Constituição Federal por meio de seus princípios protetores do trabalho, da vida e do trabalhador busca coibir e minimizar esta prática, haja visto que o assédio moral envolve uma questão de ordem constitucional, uma vez que viola princípios e garantias estabelecidos na $\mathrm{CF} / 88$, bem como direitos e liberdades há muito conquistados pelos trabalhadores, expressos tanto na CLT como em leis esparsas.

Não há dúvidas de que a prevenção à conduta perversa do assédio moral no ambiente de trabalho é de extrema importância e tem gerado bons resultados uma vez que possibilita uma melhora no ambiente laborativo. Muito se tem debatido acerca das várias formas de prevenção, como o caso da atuação dos Sindicatos, a intervenção do Ministério Público do Trabalho e as ações empresariais que procuram adequar seu meio de trabalho à realidade vivida por cada empresa, visando sempre a diminuição e a coibição desta prática que tanto atinge negativamente o trabalhador.

O trabalho a ser feito nas organizações é uma reeducação de valores que implica uma mudança cultural, com incentivo à prática do diálogo constante e permanente e a implantação de código de ética e de conduta de todos os empregados, inclusive as chefias, baseado no respeito mútuo e no companheirismo, a partir daqui é que as conseqüências de todo o processo de tirania podem vir a serem minimizadas. 
Por tratar-se de um debate relativamente atual, a legislação inda caminha a passos pequenos. São poucos os municípios que possuem uma legislação específica sobre o assédio moral. Contudo, muitos projetos de lei têm sido debatidos e apresentados e outros já se encontram em tramitação no Congresso Nacional, buscando sempre uma solução que iniba a conduta dos assediadores.

Ademais, a tendência pela qual caminha a jurisprudência nacional também leva a crer que se está a um passo da aprovação de uma norma coatora de efeito em todo o território brasileiro.

A humilhação, que é a maior e preponderante característica do assédio moral, na vida do trabalhador, precisa ser combatida sob todos os ângulos. O mais importante é que o ofendido procure os seus direitos, não pela questão da reparação em espécie, mas pela simples razão de recompor a sua auto-estima e saúde psíquica.

\section{Referências}

ALKIMIM, Maria Aparecida. Assédio moral na relação de emprego. Curitiba: Juruá, 2005.

BARRETO, Margarida. Uma jornada de humilhações. Jornal Folha de São Paulo, São Paulo, 25 nov. 2000.

DEJOURS, Christople. A banalização da injustiça social. 3 ed. Rio de Janeiro: Fundação Getúlio Vargas, 2000.

DELGADO, Mauricio Godinho. Curso de Direito do Trabalho. 5 ed. São Paulo: LTr, 2006.

FERREIRA, Hádassa Dolores Bonilha. Assédio Moral nas Relações de Trabalho. 1 ed.

Campinas: Russel Editores, 2004.

GUEDES, Marcia Novaes. Terror Psicológico no Trabalho. 2 ed. São Paulo: Ltr, 2006.

HEMETÉRIO, Rilma Aparecida. Assédio moral no trabalho. Revista IOB, vol. 17, no 208, Outubro, 2006.

HIRIGOYEN, Marie-France. Assédio moral: a violência perversa no cotidiano. Trad. de Maria Helena Kuhner. 3 ed. Rio de Janeiro: Betrand Brasil, 2002.

LEITE, Carlos Bezerra. Curso de direito processual do trabalho. 5 ed. São Paulo: LTr, 2007. 
MAZZNI, Fernanda. Ambiente de trabalho deve ser humanizado. Folha de Londrina, Folha economia, 28 de outubro de 2006.

MENDONÇA, Martha Halfeld Furtado de. O assédio moral no direito do trabalho. Revista de Direito do Trabalho, São Paulo, v. 27, n. 103, jul./set. 2001.

MENEZES, Cláudio Armando Couce de. Assédio moral e seus efeitos jurídicos. Revista de Direito do Trabalho, São Paulo, v. 28, n. 108, out./dez. 2002.

OLIVEIRA, Euler Sinoir. Assédio Moral: sujeitos, danos à saúde e legislação. Revista de Direito do Trabalho, São Paulo, v. 30, n. 114, abr./jun. 2004.

OLIVEIRA, Paulo Eduardo. O dano pessoal no direito do trabalho. São paulo: LTr, 2002.

PASCHOAL, Luiz. Gestão de pessoas na Micros, Pequenas e Médias empresas. Para empresários e Dirigentes. Rio de Jeneiro: Qualitymark, 2006.

PASTORE, José. Faltam empregos e sobram vagas. O Estado de S. Paulo, 20 set. 2005. Disponível em: <http://www.josepastore.com.br/artigos/emprego>. Acesso em: 18 fev. 2007.

PELI, Paulo. Assédio moral: uma responsabilidade corporativa. São Paulo: Ícone, 2006.

RIBEIRO, Schirlei Azevedo. Relato sobre assédio moral no Fórum Social Mundial. 2005. Disponível em: <www.nesc.ufrj.br/assediomoral>

RUFINO, Regina Célia Pezutto. Assédio Moral no âmbito da empresa. São Paulo: LTR, 2006.

RUPRECHT, Alfredo J. Os princípios do direito do trabalho. Tradução Edílson Alkmim Cunha. São Paulo: LTr, 1995.

SALVADOR, Luiz. Assédio moral. Doença profissional que pode levar à incapacidade permanente e até à morte. Jus Navigandi, Teresina, v. 6, n. 59, out. 2002. Disponível em: <http://jus2.uol.com.br/doutrina/texto.asp?id=3326>. Acesso em: 17 out. 2006.

SANTOS, Enoque Ribeiro dos. O dano moral na dispensa do empregado. 3 ed. rev. e ampl. São Paulo: LTr, 2002.

SANTOS, Luciany Michelli Pereira dos. O dano à integridade psíquica e moral decorrente de assédio moral e violência perversa nas relações cotidianas. Revista de Ciências Jurídicas/Universidade Estadual de Maringá, Curso de Mestrado em Direito, v. 1, n. 1, Maringá, Pr: Sthampa, 2003. 
SILVA, Antonio Alves da. Flexibilização das relações de trabalho. São Paulo: LTr, 2005.

THEODORO JUNIOR, Humberto. Dano Moral. São Paulo: Juarez de Oliveira, 2001.

ZIMMERMANN; Santos; Lima. Revista do Ministério Público do Trabalho, v. 9, n. 25, p. 99112, mar. 2003. Disponível em: <www.prt12mpt.gov.br>. Acesso em: 19 mar. 2007. 
